\title{
LA PUBLICIDAD COMO CONSTRUCCIÓN SEMIÓTICA
}

\section{Advertising as semiotic construction}

\author{
Rita María Pérez \\ Doctora en Filosofía en un Mundo Global, Universidad del País Vasco (UPV/EHU). Orcid: 0000-0002-9713-0615. \\ ritamariaperezperez@yahoo.es
}

Recibido: 10/3/2018 • Aprobado: 16/4/2018

Cómo citar: Pérez, R. M. (2018). La publicidad como construcción semiótica. Ciencia y Sociedad, 43(2), 11-23.

doi: http://dx.doi.org/10.22206/cys.2018.v43i2.pp11-23

\section{Resumen}

El ensayo que presentamos a continuación constituye una reflexión teórica filosófica en la que se analiza la estrecha relación entre semiótica y publicidad. El trabajo parte del razonamiento de Roland Barthes sobre la función semiótica de las imágenes y de las palabras. Estas no solo crean el sentido de los mensajes publicitarios, sino que influyen en las decisiones de compra de sus destinatarios. El producto semiotizado es capaz de irradiar significados diversos (guardados en la memoria de los destinatarios), hasta el extremo de que el receptor puede adquirir el artículo como una forma de apoderarse de los símbolos y significados que la publicidad ha impregnado a las mercancías. Sin embargo, la presencia de la publicidad $-y$, de manera particular, de sus imágenes- es tal que influye en la percepción de los individuos.

Palabras clave: lenguaje simbólico; publicidad; semiótica; percepción.

\begin{abstract}
The essay that we present below constitutes a philosophical theoretical reflection in which the close relationship between semiotics and publicity is analyzed. It starts with the reasoning of Roland Barthes on the semiotic function of images and words. Not only do they create the meaning of advertising messages, but they influence the purchasing decisions of their recipients. The semiotized product is able to radiate various meanings (stored in the memory of the recipients), to the extent that the receiver can acquire the product as a way to seize the symbols and meanings that advertising has introduced into the goods. However, the presence of advertising -and, in particular, of its images- is such that it influences the perception of individuals.
\end{abstract}

Keywords: symbolic language; advertising; semiotics; perception. 


\section{Introducción}

La publicidad es un medio de comunicación que surge con el propósito de informar al público sobre la existencia de un determinado producto, de manera que su origen y su desarrollo están ligados a los intercambios productivos que han tenido lugar a lo largo de la historia de la sociedad humana. Sin embargo, en la década de los años noventa del siglo pasado, el avance de la producción, en cantidad y en calidad, así como el aumento de la competitividad, constituyen los grandes retos para conseguir la atención de los receptores, por lo que la publicidad tiene que buscar nuevas estrategias para atraer a los clientes. En este proceso, el uso de las imágenes y de las palabras referidas al entorno físico y cultural de los destinatarios es una herramienta básica. De modo que explicitar la relación existente entre semiótica y publicidad es de especial importancia para el presente estudio, al que mueve una clara preocupación filosófica. En efecto, las páginas que siguen se esfuerzan por pensar en esa parcela de la realidad que es la publicidad, tratando así de contribuir a aportar algo de luz sobre nosotros mismos $\mathrm{y}$ sobre el mundo en que vivimos.

\section{Las imágenes como fundamento para la construcción del sentido}

En el libro El sistema de la moda y otros escritos, Barthes (2003, p. 14) argumenta sobre la función semiótica que desempeñan las imágenes y las palabras en la creación del sentido de los mensajes publicitarios y sobre el peso que esto tiene para las decisiones de compra de los destinatarios. Tal como afirma:

La sociedad industrial, calculadora, está condenada a formar consumidores que no calculan. [...] La Moda, como todas las modas, descansa sobre una disparidad de las dos conciencias: una debe ser ajena a la otra. Para obnubilar la conciencia contable del comprador es necesario extender ante el objeto un velo de imágenes, razones, sentidos, elaborar una sustancia mediata que lo envuelva, de orden aperitivo, crear, en suma, un simulacro del objeto real, sustituyendo el premioso tiempo del desgaste por un tiempo soberano, libre de destruirse a sí mismo [...] Lo que suscita el deseo no es el objeto sino el nombre, lo que vende no es el sueño sino el sentido". (Barthes, 2003, p. 14)

Susan Sontag (1981) corrobora los argumentos anteriores cuando subraya que las imágenes en el capitalismo poseen una amplia significación. La fotografía, por ejemplo, constituye un medio para dinamizar la sociedad, el comercio y la industria. "Una sociedad capitalista requiere de una cultura basada en imágenes. Necesita suministrar muchísimo entretenimiento con el objeto de estimular la compra y anestesiar las lesiones de clase, raza y sexo" (Sontag, 1981 citada en Berger, 2013, p. 76). Por tanto, aglutina una amplia cantidad de información para convencer a la sociedad sobre la necesidad de explotar la naturaleza y sus recursos. Ellas funcionan "como un espectáculo (para las masas) y con el objeto de vigilancia (para los gobernantes)" (Ibid.). No solo sensibilizan y cautivan a los receptores, sino que sirven para transmitir la ideología que domina.

Las imágenes son más significativas que los discursos, no porque su mensaje sea más completo, sino porque es inferior, pero más rápido y más verídico. Ellas "son mucho más aptas para comunicar acciones o desbordamientos pasionales que razonamientos [...] La imagen es inigualable para conmover, pero deficitaria, y aun francamente inepta, cuando se trata de sopesar y decidir" (Savater, 1993, pp. 2-3).

Crear un universo de impresiones positivas requiere de factores visuales que permitan conectar el argumento que se narra con el entorno de los destinatarios. Y, en la publicidad, la eficacia comunicativa aumenta cuando se retrata el contexto de 
los clientes. Tales son las publicidades del Salami Induveca y de la cerveza Presidente, en República Dominicana; y Mahou, en España, por citar algunos ejemplos.

El paisaje tiene un amplio valor simbólico, como manifestación de la memoria personal y social del ser humano. Caballero (1943), al referirse a los gauchos argentinos y a los llaneros de Venezuela y de Colombia, explica que, a pesar de que no se conocen, de que poseen particularidades raciales diferentes y de que están separados por una gran zona geográfica, los espacios se convierten en significantes de sus vidas y se reflejan en la expresión de las costumbres, en la añoranza de las canciones, en el amor y en el entusiasmo que manifiestan hacia la libertad, pero también en "el culto por el valor personal y hasta [en] la nostalgia que se apodera de unos y otros, lejos de sus pampas y sus llanos" (Caballero, 1943 citado por Aponte, 2003, p.154).

Así mismo, Aponte (2003) argumenta que el contexto físico es uno de los fundamentos para el desarrollo del pensamiento y de la creatividad del ser humano. El mismo sirve de base para la conformación psicológica, para el cultivo de la personalidad y de la identidad; $y$, por eso, determina en gran medida su manera de pensar, de sentirse y de actuar. Afirma que "[...] El paisaje forma al individuo, define el carácter de quienes cotidiana e ineludiblemente lo perciben, lo cual es válido no sólo en relación con el paisaje natural, sino también con el paisaje construido, ya que primero las personas construyen la ciudad y los edificios; luego la ciudad construye a las personas" (Aponte, 2003, pp. 154-155).

Gregori (2002), al analizar los procesos que desarrolla la mente humana, se refiere a las zonas en las que se ejecutan las distintas actividades: en la parte izquierda del cerebro se sitúa la racionalidad y el intelecto; en la parte inferior central, la experiencia práctica y las habilidades; y, en la zona derecha, el arte y lo relativo a los juegos. Esta última zona lúdica albergaría los símbolos propios del espacio físico, es decir, "la manifestación tangible del lugar, en una palabra, al paisaje, convirtiéndolo en inspirador de manifestaciones estéticas y en buena parte responsable de la 'emoción del yo'" (Arciniegas, 1972 citado por Aponte, 2003, p. 159). En otras palabras, el contexto físico contribuye a formar el carácter del individuo fundamentalmente durante los siete primeros años de existencia y, luego, el desarrollo del cerebro, "en especial a uno de los tres procesos mentales: el de las operaciones intuitivo-sintéticas" (Gregori, 2002, citado por Aponte, 2003, p. 159).

El receptor del mensaje a través de las imágenes publicitarias se visualiza en su contexto, pero alejado de los problemas cotidianos, aunque se le ofrece la compra de la mercancía como única vía para formar parte de esa realidad. Es decir, que la narrativa visual ayuda a construir un orden semiótico y a producir significados debido a que los elementos que intervienen en ella adquieren sentido como resultado de la sucesión entrelazada de acontecimientos. Esta funciona como un esquema mental, va llevando al "lector" hacia el propósito de la publicidad y sirve de refuerzo para memorizar y recordar el mensaje por largo tiempo. Así, mediante la presentación de imágenes, en las que aparece el deseo como móvil del relato publicitario, los creativos de las empresas de publicidad crean en los consumidores la sensación de que ese deseo es real.

Sánchez (1997, p.35) explica que la publicidad es una práctica mercantil y discursiva en la que se presenta una equivalencia ejemplar entre el contexto lejano que esta presenta y las funciones que Propp denomina "carencia" y "eliminación de la carencia", que permiten que el relato pueda ser analizado como una continuidad de ciclos, de "degradaciones" y de "mejoramientos", donde lo que circula entre los sujetos son "objetos de valor", los cuales, en la narración publicitaria, pueden transmitir su función actancial a las mercancías. Así, los productos "semantizados por los valores connotativos y simbólicos que les atribuye la semiosis narrativa, [contribuyan a eliminar] 
las supuestas carencias iniciales del consumidor" (Ibid.). Incluso, en los países que tienen la capacidad para crear riqueza y para preservar la prosperidad y el bienestar económico y social de sus habitantes, la narrativa visual es utilizada para simular emociones y provocar la escasez.

\section{Las palabras como base para la semiótica publicitaria}

La lengua es también una herramienta fundamental en la publicidad. Su uso está asociado al interés por llevar al inconsciente de los consumidores el sello distintivo de un determinado grupo social. Es un instrumento simbólico que ayuda a que el receptor mire la mercancía desde una óptica positiva y cercana, lo cual facilita su recuerdo.

Eco (2000, p. 22) destaca el valor filosófico de la semiótica ${ }^{1}$ desde su propia fundación y hace hincapié

1. La semiótica ha sido utilizada como herramienta teórica para estudiar los lenguajes sígnicos de manifestaciones culturales diversas, tales como medicina, arquitectura, pintura, escultura, cine, literatura, teatro, juegos, vida cotidiana, festividades, religiosidad, televisión, protocolos, gestualidad y publicidad. Eco (2000, p. 22), en su obra Tratado de Semiótica General escribe: "La semiótica se ocupa de cualquier cosa que pueda considerarse como signo. Signo es cualquier cosa que pueda considerarse como sustituto significante de cualquier otra cosa. Esa cualquier otra cosa no debe necesariamente existir ni debe subsistir de hecho en el momento en que el signo la represente. En ese sentido la semiótica es en principio la disciplina que estudia todo lo que puede usarse para mentir".

"Si una cosa no puede usarse para mentir, en ese caso tampoco puede usarse para decir la verdad: en realidad, no puede usarse para decir nada. La definición de 'teoría de la mentira' podría representar un programa satisfactorio para una semiótica general". La semiótica, en tanto metodología científica, abierta y flexible, permite llevar a cabo estudios convincentes del discurso publicitario, pues nos ayuda a descubrir mensajes verbales, icónicos y simbólicos, que pueden pasar inadvertidos para otras metodologías. En ese sentido, tiene en cuenta la ideología, la cultura, la mentalidad, el poder adquisitivo, el nivel educacional y las expectativas estéticas tanto del emisor, como del público al cual está dirigido el mensaje. 5. Este recrea el encuentro entre indígenas y europeos, y actualmente se encuentra en la residencia del Sr. Andreas Lapp. en la importancia del ser humano como productor de signos y como expresión de sus propios signos y símbolos. Es decir que en la palabra se deposita el léxico ${ }^{2}$ sociocultural en el que se traducen y representan las formas de los recuerdos y las vivencias de una sociedad (Bajtin, 1982, p. 45). Esto significa que las prácticas lingüísticas generan prácticas significantes que están relacionadas de forma directa con sistemas históricos y los significantes son expresiones sociales que forman parte de un código condicionado por el contexto ${ }^{3}$ de una época ${ }^{4}$ (Saussure, 1993, p. 16). Esto, dicho en otros términos, equivale a que en el proceso de semiosis los signos son captados por los interpretantes, que se convierten en factor necesario para la circulación del sentido y, por tanto, en protagonistas del acto de la semiotización, lo que significa que "la palabra o signo que el hombre usa es el hombre mismo... así mi lenguaje es la suma total de mí mismo" (Peirce, 1931, p. 189).

2. "[... ¿ ¿Y qué es un léxico? Un léxico es una porción del plano simbólico (del lenguaje) que se corresponde con un corpus de prácticas y técnicas; este es exactamente el caso de las diferentes lecturas de la imagen: cada signo se corresponde con un corpus de 'actitudes': el turismo, el trabajo doméstico, el conocimiento del arte..., algunos de los cuales pueden, por supuesto, ser ignorados por un individuo. En un mismo individuo se da la pluralidad y la coexistencia de léxicos; el número y la identidad de estos léxicos forman, en cierto modo, el idiolecto de cada persona. La imagen, en su connotación, estaría constituida entonces por una arquitectura de signos extraídos de una profundidad variable de léxicos (de ideolectos), y cada léxico, por "profundo" que sea, seguiría estando codificado, si, como actualmente se piensa, la misma psique está articulada como un lenguaje; es más: cuanto más se 'desciende' a las profundidades psíquicas de un individuo, más se rarifican los signos y más clasificables se vuelven: ¿hay algo más sistemático que las lecturas de los tests de Rorschach? (Barthes, 1986, pp. 42-43).

3. Existe un vínculo entre los signos y los comportamientos sociales, en tanto que los signos son una expresión de la psicología social.

4. Por ejemplo, el verbo "digitalizar" es producto del desarrollo sociotecnológico de finales del siglo xx, el cual está asociado a la invención del ordenador. 
Zambrano (2009, p. 63) subraya que el uso de una lengua determinada:

[...] permite que seamos aceptados por una comunidad, grupo, sector o persona en específico, que éstos nos den y exijan lo mismo que a los otros. El hablar de cierta manera nos facilita las cosas en lo que respecta a las relaciones con quienes nos rodean. Cuando hablo así influyo sobre los demás, hago que me acepten y me favorezcan, pareciera ser el razonamiento instintivo del hablante, hecho comprobable desde el punto de vista de la experiencia cotidiana. La adaptación lingüística debe entenderse como parte del instinto de supervivencia.

Lo anterior significa que acomodar la manera de hablar al lugar en el que se desarrolla la comunicación es una forma de identificarse con el entorno y con las personas que lo habitan. En la publicidad muchos textos emplean determinados dialectos para que el destinatario interprete 5 el sentido que llevan implícito (Eco, 1986; Coseriu, 1992, p. 173). Sobre esto, Baudrillard (1970, p. 228) afirma:

[...] la publicidad imita los modos de comunicación próximos, intimistas, personales. Trata de hablar al ama de casa con el lenguaje del ama de casa de enfrente, trata de hablar al ejecutivo o a la secretaria como su director o su colega, trata a cada uno de nosotros como su amigo, o su superego, o como una voz interior a la manera de confesión. De este modo, produce allí donde no la hay, ni entre los hombres, ni entre ellos y los productos, intimidad, según un verdadero proceso de simulación.

Las variantes sociolingüísticas contribuyen a que el público se identifique con el mensaje, además

5. No obstante, Eco (1986) señala que al manifestar de forma tan exacta la manera en que hablan algunas personas, los medios de comunicación transmiten un mensaje que, lejos de servir de modelo educativo para los más pequeños, les hace pensar que esa es la forma correcta porque es la que ven o escuchan. de que le ayudan a la publicidad a delimitar el sexo, la edad, la clase social o la región, entre otras características de los destinatarios. Por ejemplo, las palabras clave o key words se emplean en publicidad según la cultura o el grupo social al que se dirige el mensaje. De este modo, "la frecuencia de las entradas casa, tu hogar, sentirse limpio, económico, cuidarse, cuerpo, secreto, piel, familia entre otras muchas son entradas propias de los anuncios femeninos y se presentan muy esporádicamente en los anuncios dirigidos a hombres" (Madrid, 2001, p. 2). Sin embargo, cada vez más los anuncios evitan hacer marcas de género, en tanto el machismo es un mal que la sociedad busca superar y ha sido muy criticado en estudios específicos sobre este tema.

Asimismo, razones sociolingüísticas encaminadas a llamar la atención de la audiencia determinada hacen que la publicidad use un idioma diferente al del país en el que se realiza el anuncio. Por ejemplo, el uso del inglés en los anuncios de Nescafé y de Volvo S80 implica al público objetivo y selecciona un target: joven, con buena educación, de la clase media o medio-alta. Igualmente, la palabra open-up puede interpretarse desde diversos puntos de vista, al establecer un juego de palabras que funcionan como impulso para mover al receptor hacia el objeto de interés publicitario. "Esta forma verbal en inglés posee tres acepciones que están voluntariamente, implicadas en el anuncio: open-up 1: destapa, abre; open-up 2: sé abierto de mente, tolerante; open-up 3: sincérate (lit: abre tu pecho a alguien)" (Madrid, 2001, p. 11). No obstante, si la persona que lo escucha no tiene competencias en el idioma inglés, el significado global que encierra el anuncio publicitario se disuelve en una canción pegajosa. Incluso, para hacer más real el ambiente y conectarlo con la denominación originaria del café, la pronunciación del inglés es propia de una variante hablada en el Caribe.

Dicho de otro modo, a través de la representación, la publicidad suplanta la necesidad de calor humano 
que posee la actual sociedad. Esto se explica porque el calor es la cualidad más sobresaliente para la opinión social. Para nadie es noticia el significado que tiene para las personas adultas haber tenido una cálida relación de contacto físico con sus mayores durante su nińez. Incluso, "la experiencia de calor físico (o frío) puede incrementar sentimientos de calidez (o frialdad), sin que la persona sea consciente de esa influencia" (Álvarez, 2011, p. 98). Por eso,

[...] el neuromarketing anima a las personas a emplear metáforas para que los pensamientos y sentimientos significativos afloren a la superficie de manera inconsciente e influyan en la toma de decisiones. Las metáforas son eficaces y contribuyen a trasladar las experiencias inconscientes a la conciencia y luego comunicarlas (Ibid., p. 99).

Incluso, ciertas metáforas no solo sirven para resumir la información, sino que la hacen impactante y seductora. Por ejemplo, en los automóviles, las palabras 'escape', 'protección', 'poder', 'estatus', 'libertad'; en alimentos: 'salud', 'naturalidad', 'modernidad', 'paz interior', 'conexión cultural'; en seguros: 'protección', 'prevención', 'restauración', 'fuente de equilibrio emocional' (Ibid., p. 99).

Dicho de otro modo, a través de la palabra la publicidad trata de "rellenar en términos semióticos el gran vacío simbólico que caracteriza nuestra época" (Caro, 2007, p. 134). Sin embargo, al hacerlo, pone "de relieve el verdadero cometido de esta incesante producción significante publicitaria, como resultado de la cual el signo y lo significado se superponen a la realidad" (Ibid.).

De manera semejante ocurre con la terminología científica: se emplea para comunicar garantía y confianza en el funcionamiento de un determinado equipo y representa un compromiso de durabilidad. Por ejemplo, la presencia en muchos aparatos de palabras como digital, computadora, entre otras, evidencia que se ejerce el máximo control tecnológico en su desempeño y se garantiza su inteligencia mecánica.

\section{El desarrollo de emociones como fundamento publicitario}

Hasta aquí hemos podido ver la función semiótica que cumplen las imágenes y las palabras en los mensajes publicitarios. Sin embargo, para entender mejor este asunto vale la pena conocer cómo actúa el consumidor ante las emociones que experimenta por medio de los anuncios.

Estudios en el campo del neuromarketing explican que el comportamiento es el resultado del papel primordial que desempeña el cerebro en la interpretación de los hechos, pues, aunque disponemos de racionalidad, somos seres emocionales. Es decir, que el receptor del mensaje, como sujeto activo, representa el mundo a través de las percepciones externas e internas. Los cinco sentidos funcionan como si fueran una interfase entre los seres humanos y el entorno que los rodea. Esto es algo que se constata cuando visualizamos una película y lloramos, por ejemplo. A pesar de que gran parte del cerebro tiene conciencia de que es una historia ficticia,

[...] la parte reptiliana del cerebro (cerebro primitivo) con su nivel primitivo de inteligencia no diferencia entre realidad y ficción de una historia bien representada. Libera un flujo de hormonas que invaden las glándulas lagrimales produciendo otras respuestas fisiológicas (presión de garganta, carraspeo o lagrimeo) (Álvarez, 2011, p. 106).

La percepción sensorial "es uno de los fenómenos más apasionantes en el campo del neuromarketing, ya que determina no sólo el posicionamiento de los productos, servicios y marcas, sino también el comportamiento y el aprendizaje del consumidor" (Braidot, 2013, pp. 33-34). Engloba un amplio número de manifestaciones que se activan por debajo del umbral de su conciencia y que, por tanto, el ser humano no registra. De ahí la importancia de las expresiones metaconscientes, relacionadas con 
la percepción, para las decisiones ${ }^{6}$ del consumidor ${ }^{7}$. De ahí que un producto puede definirse como "una construcción cerebral" (Ibid., p. 34), pues la visión que el consumidor tiene de él depende tanto de factores externos como de factores internos -entre los que se encuentran, por un lado, las cualidades físicas de la mercancía, el precio y la publicidad; y, por otro, las experiencias del cliente, la personalidad, la historia, los valores y el modo de vida, etc.-.

Las emociones constituyen el argumento para la existencia de las marcas. Estudios actuales sobre "inteligencia emocional" prueban su legitimidad y recomiendan trabajarlas para que broten de manera involuntaria del subconsciente. Por ejemplo, companías como Coca-Cola, Procter\&Gamble, Unilever, Nestlé, Hallmark, Glaxo o Apple han desarrollado investigaciones para analizar emociones determinadas y observar variaciones casi imperceptibles sobre la manera en que proceden (Álvarez, 2011, p. 45).

La emoción motiva y no es casual que ambas palabras deriven de la misma raíz griega. Sentimos amor, interés, sorpresa, temor, animosidad u odio según el significado que se infiere de las experiencias y pensamientos. De hecho, la emoción es la fuerza motivadora

6. Según las investigaciones realizadas sobre neuromarketing sensorial "el sonido que produce un alimento al morderlo es tan determinante sobre las preferencias del cliente como su aroma, sabor o apariencia. [...] En la primera rotura que sufre una galletita al ser mordida se libera energía en forma de ultrasonidos con una frecuencia mayor a la que podemos oír, y que, sin embargo, es captada por el sistema auditivo y puede provocar rechazo en el cliente sin que él sea consciente de este proceso" (Braidot, 2013, p. 35).

7. En el caso de los aromas, por ejemplo, se expone a los participantes de una muestra representativa a ambientes perfumados con diferentes fragancias sin informarles sobre estas variaciones, evitando que focalicen su atención en este aspecto. En todos los casos, mientras se registran sus reacciones, no varía la ubicación de los productos. Lo único que cambia es el aroma. Posteriormente, los investigadores analizan si hubo cambios en el comportamiento y, a partir de ello, se elige una entre las opciones que estuvieron bajo estudio (Braidot, p. 36). más importante conocida en el ser humano. (Ibid., p. 45)

Incluso, hoy se sabe que la parte del cerebro que se pensaba "libre de emociones" para la adquisición de artículos de tecnología punta, toma decisiones que dependen de elementos emocionales ${ }^{8}$ vinculados con la marca y no con aspectos objetivos, como el precio o la función. Por eso, el concepto de marca ha sido trabajado para construir una gran cosmovisión y lograr que su posicionamiento en el mercado sea proporcional a su imaginario: un ejemplo de esto es Intel Incide, el mayor fabricante de circuitos integrados. Es decir que "las marcas existen en la mente pero actúan en el corazón (Álvarez, 2011, p. 45).

Las emociones cristalizan como el objetivo hacia el cual la publicidad dirige sus mensajes, como la manera más rápida de influir sobre la audiencia objetiva, tal como ratifica el experimento del científico Read Montague . Es decir, que el cerebro actúa de modo diferente ante una marca conocida que ante una que no conoce. Cuando existe una estrecha

8. Braidot (2013, p. 15) argumenta que durante los años noventa o "década del cerebro" se pudieron confirmar algunas creencias del marketing tradicional, "como la eficacia de la publicidad emocional en la fidelización de clientes o la falacia de atribuir al consumidor una conducta racional, por ejemplo".

9. En dicho experimento se sometió a un grupo de consumidores a pruebas de resonancia magnética funcional (fMRI) para comparar su actividad neuronal frente al consumo de Coca Cola y de Pepsi, las marcas de refrescos más vendidas en el mundo, y poder verificar la preferencia de ellos por una de estas.

El ensayo demostró que en el test ciego, basado en el sabor, los consumidores seleccionaban Pepsi, mientras que en el test vidente, basado en la imagen de la marca, el 75\% del grupo prefería Coca Cola. Situación que lo llevó a concluir que existe una lucha entre la razón y la emoción que trae consigo una breve indecisión, pero luego de ese lapso, vence la emoción. Por eso "la historia, los recuerdos de infancia, los colores y la simple identidad emocional que se establece entre el consumidor y Coca Cola le sirve para desbancar a las bebidas de la competencia. [...] La 'batalla' dentro de un mercado fuertemente competitivo y con gran cantidad de características semejantes se juega en el campo de las emociones y no de la razón (Feenstra, 2013, p. 50). 
relación con el producto, la región del cerebro encargada de la reflexión y del raciocinio -el neocórtex- relaja su actividad y baja su nivel de activación. Así ahorra energía y activa la zona de emociones, facilitando la acción instintiva e irreflexiva por parte del consumidor (Feenstra, 2013, p. 50).

Entonces, el éxito de la publicidad está determinado en gran medida por su facultad para activar dos partes del cerebro: el sistema límbico-que tiene que ver con las emociones- y el cerebro reptiliano -encargado de controlar las conductas instintivas y las necesidades primarias: hambre, deseos sexuales y temperatura corporal- y evitar que el neocórtex (que se encarga del razonamiento abstracto y del lenguaje) impida que se atrase o se evite la compra.

Manes (2011, XvI), presidente de la World Federation of Neurology Research Group on Aphasia and Cognitive Disorders, reafirma lo dicho hasta aquí. "La toma de decisión es un proceso que depende de áreas cerebrales involucradas en el control de las emociones" y, estas a su vez, son el fruto del dominio que ejerce el entorno social en la multiplicidad del desarrollo del cerebro. Las emociones son:

[...] consecuencia, en parte, de la complejidad social que ha alcanzado nuestra especie a lo largo de su evolución. El ser humano es, básicamente, una criatura social. Es por ello que crea organizaciones que van más allá del propio individuo, desde la familia hasta comunidades nacionales, globales $y$, más recientemente, en la era de Internet, comunidades virtuales. (Ibid., p. xv)

El ser humano todo el tiempo está tomando decisiones, pero la velocidad con la que lo hace le impide racionalizar cuáles son las ventajas e inconvenientes de cada una, además de que están conectadas a diferentes regiones del cerebro y dependen de la zona que salga victoriosa en una lucha que se produce entre "los centros emocionales y racionales. La idea de que somos seres conscientes, con poder para realizar nuestras propias elecciones ha sido cuestionada" (Manes, 2011, p. XVI).

\section{Las imágenes publicitarias como cimiento para una nueva percepción}

La publicidad en la sociedad de consumo no solo es un medio de información, sino que constituye un patrón de referencia permanente para el ser humano en su relación con el entorno y con sus semejantes: implanta la moda e influye en las distintas esferas de la economía, de la política y del pensamiento humano; además de que genera, propaga y fomenta costumbres en la sociedad. Su presencia interviene en casi todos los ámbitos de la vida moderna e influye en la percepción que los seres humanos tienen sobre la realidad.

Los carteles, los anuncios de prensa, las cuñas de radio, las películas de televisión y las páginas de internet acompañan la vida cotidiana contemporánea, según afirma Berthelot-Guiet (2015). Pero no solo eso; tal es su influjo que quien se interese por comprender las producciones que circulan hoy en los medios de comunicación no puede pasar por alto los discursos publicitarios ${ }^{10}$ (la autora analiza de manera específica el caso de la sociedad francesa). A propósito, algunas de las series televisivas han sido creadas para publicitar determinados artículos y este no es un caso aislado, es una situación que se repite en películas, novelas y dibujos animados, por solo mencionar algunos ejemplos.

El diseño urbanístico que predomina tras la Segunda Guerra Mundial responde a una economía ${ }^{11}$ de

10. Sobre esta cuestión, Sloterdijk (2012, p. 468) tiene una opi-
nión parecida, cuando expresa que ante la "actual fase de satura-
ción de anuncios publicitarios: un sinnúmero de gente querría
sustraerse a la omnipresencia de la publicidad, huyendo de ella
como de la peste". Si bien reconoce el valor de la publicidad
como medio para informar a la sociedad de los avances cientí-
ficos y tecnológicos, juzga pertinente diferenciar un antes y un
ahora, en el papel que ha desarrollado.
11. A diferencia de la publicidad convencional -hecha a través 
mercado. Esto explica por qué muchos autores coinciden al señalar que se ha perdido el sentido de socialización y que los espacios urbanos se han transformado en centros de intercambio económico, mercantil y financiero. Los espacios "han sido disueltos y sustituidos por lugares homogéneos y estandarizados, deshumanizados -los no-lugares de Marc Augé, definidos por la no-identidad y la no-relación-, lugares de ocio de masas o de consumo, que han originado nuevas centralidades urbanas: grandes superficies comerciales, supermercados, centros de ocio, aeropuertos, estaciones..." (Aguilera, 2004, p. 37).

Los escenarios que presenta la publicidad y que vivimos a través del cine y de las series de televisión llevan al ser humano a alejarse de la realidad y a expresar un conocimiento inexacto del mundo en que vive. Nietzsche (1873), cuando habla sobre el origen del lenguaje y su sentido metafórico, reflexiona sobre la influencia de las imágenes en este proceso y observa que su nacimiento está relacionado con la extraordinaria capacidad de la mente humana para construir metáforas y equivalencias que tienen como punto de partida el mundo real y concreto, que sirve de estímulo a la imaginación y al intelecto para crear el lenguaje. Este es un aspecto que Galparsoro (2009, pp. 97-106) ratifica cuando se refiere a "la cuestión de la primacía de lo visual en el pensamiento occidental”, y

del cine, la TV, la radio, los periódicos, las revistas y el Internet-, el soporte publicitario que utilizan los carteles y las vallas públicas forma parte del paisaje de la ciudad y del entorno en el que se desarrolla la vida de sus gentes, por eso provoca desequilibrio y falta de armonía espacial. De ahí la necesidad de que la publicidad, dentro del paisaje urbano, contribuya a su ambientación. "Algunos autores ven en este elemento su carácter positivo en cuanto factor decorativo: la luz y el color de los carteles vendría a decorar el triste y gris escenario urbano de las ciudades industriales. Otros, sin embargo, ven los peligros que puede representar una política anárquica del cartelismo publicitario, además de que, desde el punto de vista técnico, una fuerte saturación del entorno visual mediante carteles puede reducir su eficacia al provocar un rechazo del receptor" (Sánchez, s.f., p. 244). agrega: "Nietzsche considera que el lenguaje - $-y$, en última instancia, la racionalidad- pasa por la mediación de la imagen: el estímulo nervioso se convierte en imagen y ésta en palabra (sonido articulado)".

Sobre este tema, Frutiger (2002, p. 167) plantea que, [...] la masiva difusión de imágenes, también en forma impresa, está a punto de hacer que cambie notablemente la psique general de la generación actual. La imagen irradiada es, por así decir, captada globalmente en un instante; no ha de ser reseguida de manera continua, a diferencia del habla, cuyo desarrollo en el tiempo sigue un curso lineal y que debe ser oída y captada sin interrupción para ser comprendida. Además, la imagen presenta su comunicación de golpe, en su totalidad, y de forma perfectamente definida y delimitada. El observador no ha de elaborar ninguna otra imagen paralela o correspondiente, como en el caso del lector o del oyente. La imagen es un producto acabado que excluye el acto imaginario de toda ulterior representación mental y que empobrece en gran medida las posibilidades configurativas de la fantasía humana. Además, la transmisión de imágenes ejerce, por así decirlo, un proceso de desmitificación, puesto que el presente actual del mundo puede ser contemplado por todos los individuos por igual. Esta abundancia de transmisiones "fotográficas" lleva a una cierta saturación de imágenes.

Incluso, desde que apareció la fotografía ${ }^{12}$, se expresa mediante ${ }^{13}$ imágenes lo que antes se hacía

12. "Mediante las fotografías el mundo se transforma en una serie de partículas inconexas e independientes; y la historia, pasada y presente, en un conjunto de anécdotas y faits divers. La cámara atomiza, controla y opaca la realidad. Es una visión del mundo que niega la interrelación, la continuidad, y el cambio confiere a cada momento un carácter misterioso" (Berger, 2013, p. 72).

13. Por ejemplo, cuando observamos la manera en que los jóve- 
con palabras. Ser parte de un universo colonizado por imágenes, provoca que todos retengamos:

[...] la mayor parte de las veces de manera inconsciente, algunas de sus características y contenidos. Pueblan nuestros entornos más cercanos, nuestras vidas, y se cuelan de rondón hacia los sentidos; toman posesión de ellos a través de los ojos. Crean un universo que influye en nosotros de muchas maneras. (Fernández, 2015, pp. 68-69)

Su dominio interviene en la aparición de un nuevo modo de experimentar las emociones y las sensaciones. La televisión, por ejemplo, más que desarrollar expectación por la lectura y servir para comprender la realidad que nos rodea, la suplanta. Este es el resultado de que el telespectador establece una relación con las imágenes que es "desde un punto de vista narrativo, un tiempo temáticamente muerto, puesto que se aplica, no a la realidad, sino a una representación" (Goytisolo, citado por Méndez, 1995). Incluso, el influjo del relato visual ${ }^{14}$ también salta a la vista cuando narramos alguna historia e imaginamos "escenas en planos generales, en planos americanos. Como en una película" (Vásquez Montalbán, citado por Fernández, 2015, p. 68).

nes y adolescentes perciben la violencia en un largometraje de ficción, nos damos cuenta de que existe un distanciamiento y una ruptura en su manera de acercarse a la brutalidad, pues la gran mayoría no se hace eco del dolor, sino que se ríen y disfrutan de lo que ocurre. Da la impresión de que más que apreciar las escenas, se sitúan del otro lado de la pantalla y analizan los trucos, juegos, maquillajes y escenarios de los que ha tenido que valerse el realizador para transportarnos a esa situación. $\mathrm{O}$, tal vez, actúan de esa manera porque se han vuelto inmunes al enfrentarse a las imágenes vandálicas que muestran muchos videojuegos o como resultado de la exposición constante a noticias relacionadas con el tema.

14. "Pese a las disparidades y servilismos entre unas artes y otras, la futura narración deberá contar tanto con la imagen como con el cambio de sensibilidad que esa presencia continuada de imágenes produce en el público" (Goytisolo, citado por Fernández, 2015, p. 69).
La avalancha de imágenes promovidas por el cine, por los canales televisivos y también por las formas gráficas contribuye a saciar la capacidad de indagación ${ }^{15}$ de los individuos y a colmar su imaginación creadora, en tanto que el mundo no se presenta enriquecido, sino esquematizado. La producción de imágenes, junto al desarrollo tecnológico de los medios de comunicación, han convertido al mundo en una aldea global en la que los hechos y las noticias se comunican instantáneamente y en la que las audiencias muestran una preferencia creciente por las imágenes televisivas $\mathrm{y}$, en cierta medida, hasta por el sensacionalismo y el impacto que ellas crean. La crítica periodística es suplantada por la presentación de imágenes, sin que apenas lo notemos. Y, a nuestro modo de ver, esto ocurre porque se necesita menos concentración y tiempo para comprender la información visual que para captar la comunicación verbal, que requiere de mayor atención y esfuerzo intelectual por parte del receptor. Una realidad que sin duda afecta a la concentración y a la capacidad de análisis y que sirve para explicar el déficit general que padecen muchos estudiantes y adultos con relación a la escucha, el cual queda evidenciado cuando participan en una conferencia o en un diálogo.

\section{Conclusiones}

Los argumentos anteriores explican el carácter semiótico de la publicidad y, por supuesto, la fusión que se establece entre las imágenes, las palabras y las emociones. Comprender cómo viene el sentido

15. “Quizá soy una aberración, un caso extraordinario. Pero no parece que sea el caso. Cuando menciono mis problemas con la lectura a algún amigo, muchos dicen que sufren de aflicciones similares. Cuanto más usan Internet, más tienen que esforzarse para permanecer concentrados en textos largos" Carr (2011, p. 19). Esto mismo les ha ocurrido a algunos de los blogueros, tal es el caso de Bruce Fridman y Scott Karp. Este último confiesa que ha renunciado a la práctica de leer los libros completamente y por eso se cuestiona " $¿ Y$ si toda mi lectura es online no tanto porque ha cambiado el modo en el que leo, es decir, por pura conveniencia, sino porque el modo en el que PIENSO ha cambiado?” (Karp, citado por Carr, 2011, p. 19). 
a las publicidades es complejo: no basta con analizar la imagen o con hacer una investigación lingüística, sociológica o histórica, pues los discursos publicitarios solo pueden ser abarcados por una conjunción de todos esos aspectos, como forma de abordar su principio comunicacional esencial. Es decir, que en busca de hacer más eficaz la comunicación, la publicidad se apoya en distintas disciplinas sociales -psicología, sociología, antropología, estadística, economía y estética, entre otras-, cada una de las cuales le aporta estrategias específicas. Y la semiótica, como ciencia de los signos, le ofrece la información indispensable sobre los recursos simbólicos, visuales y verbales que intervienen en dicho proceso, a la vez que contribuye a la funcionalidad de estos, en la medida en que ayuda a disminuir ${ }^{16}$ la complejidad de su integración y los amalgama sabiamente para mover las emociones de sus destinatarios.

Las campañas publicitarias, con sus anuncios, están dirigidas al público en general, el cual, de alguna manera y en algún tiempo de su existencia, recibe las señales del mensaje publicitario. No obstante, toda campaña publicitaria está orientada directamente a un público objetivo o específico, que puede descifrar con cierta facilidad el mensaje

16. Berthelot-Guiet (1998) ha conducido una investigación sobre una muestra representativa de la población de París. En ella ha seguido un método riguroso para saber cuáles expresiones inventadas por y para la publicidad han pasado a formar parte de la lengua corriente, cuáles connotaciones, por cuánta duración y a veces cuáles cambios han adquirido estas. En su artículo "Publicité: une parole quotidienne?", reafirma la influencia que tiene la publicidad en la manera de hablar y de comportarse los receptores de los mensajes. Sin embargo, exalta la labor de la publicidad para mantener viva la lengua. La publicidad toma prestados elementos de la lengua de la calle, pero recíprocamente el lenguaje cotidiano adopta los eslóganes publicitarios más chocantes y, al hacerlo, la lengua de la publicidad se convierte en parte del hablar cotidiano de la sociedad, al tiempo que le ofrece un soplo de vida a través de frases vivaces y despropósitos que hacen al habla maravillosamente libre e inesperada y convierten a este proceso en un juego de cultura y de referencias que engalanan la lengua a través de palabras, imágenes y giros literarios. publicitario, en virtud de condicionantes individuales, sociales y culturales -en los que intervienen el sexo, la edad, el nivel educativo, la filiación política, religiosa, ideológica y la clase social a la que pertenece- que tienen que ver con el contexto en el que vive. $Y$ este es un aspecto que contribuye a propagar al resto de la sociedad las costumbres, la música y/o las expresiones lingüísticas del público objetivo y determina, en gran medida, sus decisiones de compra.

La publicidad es parte del mundo que nos rodea. La relación que se establece entre las dos partes tiene lugar en el doble sentido: la publicidad es un reflejo de la realidad y, a la vez, ejerce su influencia sobre ella. Este ensayo ha intentado precisamente, con las herramientas conceptuales provenientes de autores y disciplinas de origen muy diverso $-y$, por tanto, desde una vocación inequívocamente filosófica- pensar la publicidad en el contexto actual.

\section{Bibliografía}

Aguilera, F. (2004). Arte, ciudadanía y espacio público. On thew@terfront, (5), marzo, 36-51. Recuperado de https://www.raco.cat/index.php/ Waterfront/article/view/214757/285049

Álvarez, R. (2011). Neuromarketing, fusión perfecta: seducir al cerebro con inteligencia para ganar en tiempos exigentes. Madrid, España: Pearson Educación.

Aponte, G. (2003). Paisaje e identidad cultural. Tabula Rasa, (1), enero-diciembre, 153-164. Recuperado de dev.revistatabularasa.org/numero-1/Gaponte.pdf

Arciniegas, G. (1972). América, tierra firme. Bogotá, Colombia: Editorial Planeta.

Barthes, R. (2003). El sistema de la moda y otros escritos. Barcelona, España: Ediciones Paidós.

Baudrillard, J. (1970). La sociedad de consumo: sus mitos, sus estructuras. Barcelona, España: Siglo XxI. 
Baudrillard, J. (1989). Publicidad absoluta, publicidad cero. Revista de Occidente, 92, enero, 5-16.

Bajtin, M. (1982). Estética de la creación verbal. México, D.F.: Siglo XXI.

Berger, J. (2013). Para entender la fotografía. México, D.F.: Gustavo Gili, SL.

Berthelot-Guiet, K. (1998). Publicité: une parole quotidienne? Communication et langages, (117), 3ème trimestre. Dossier. La publicité au microscope, 12-27. Recuperado de www.persee.fr/doc/ colan_0336-1500_1998_num_117_1_2861

Berthelot-Guiet, K. (2015). Analyser les discours publicitaires. París, Francia: Armand Colin.

Braidot, N. (2013). Neuromarketing: ¿Por qué tus clientes se acuestan con otro si dicen que les gustas tú? Barcelona, Espańa: Gestión 2000.

Caro, A. (2007). Jean Baudrillard y la publicidad. Pensar la publicidad, I(2), 131-146.

Carr, N. (2011). ¿Qué está haciendo Internet con nuestras mentes? Superficiales. Madrid, España: Taurus.

Coseriu, E. (1992). Competencia lingüistica. Madrid, España: Gredos.

Eco, U. (1986). La Estrategia de la Ilusión, Lumen, Barcelona.

Eco, U. (2000). Tratado de semiótica general. Barcelona, España: Lumen.

Feenstra, R. (2013). La irrupción de la neuropublicidad y sus debates éticos. Revista Internacional de Filosofía, (59). 45- 56. Recuperado de https:// www.researchgate.net/publication/305773036_ La_irrupcion_de_la_neuropublicidad_y_sus

Fernández, J. I. (2015). Cuando la luz cambió. Fotoperiodismo. Transición, 1975-1982. Santander, España: Milrazones.
Frutiger, A. (2002). Signos, simbolos, marcas, señales. Barcelona, España: Gustavo Gili.

Galparsoro, J. I. (2009). Nietzsche y la cuestión de la primacía de lo visual en el pensamiento occidental. En J. Aguirre, I. Ceberio \& O. González (eds.), Racionalidad, visión, imagen. Madrid, España: Plaza y Valdés.

Gregori, W. de (2002). Construcción familiar-escolar de los tres cerebros. Bogotá D.C., Colombia: Editorial Kimpres Ltda.

León, J. L. (2001). Mitoanálisis de la publicidad. Barcelona, España: Editorial Ariel.

Lipovetsky, G. (1990). El imperio de lo efimero: la moda y su destino en las sociedades modernas. Barcelona, Espańa: Anagrama.

Madrid, S. (2001). La variación sociolingüística en publicidad. Análisis sociolingüístico de textos publicitarios televisivos. Revista Electrónica de Estudios Filológicos, (1), 1-51. Recuperado de https://www. um.es/tonosdigital/znum1/download/soniamadrid.PDF

Manes, F. (2011). Prefacio. Neuromarketing, fusión perfecta: seducir al cerebro con inteligencia para ganar en tiempos exigentes. Madrid, España: Pearson Educación.

Méndez, J. (1995, 30 de enero). Luis Goytisolo reivindica la autonomía de la palabra frente a la imagen. El Pais. Recuperado de https://elpais.com/ autor/jose_mendez/a

Nietzsche, F. (1873). Sobre verdad y mentira en sentido extramoral. Obras completas (vol. I): escritos de juventud. Madrid, España: Tecnos.

Peirce, C. S. (1931). Colleted Papers, vol. 5, (edición a cargo de Charles Hartshorne y Paul Weiss). Cambridge, MA. USA: Harvard University Press.

Reinares, P. \& S. Calvo (1999). Gestión de la comunicación comercial. Madrid, España: McGRAWHILL/Interamericana de España. 
Roig, M. (2008). "Soy ciego y hoy comienza la primavera" (Prólogo). Storytelling la máquina de fabricar historias y formatear las mentes. Barcelona, España: Península.

Sánchez, L. (1997). Semiótica de la Publicidad. Madrid, España: Síntesis.

Sánchez, J.R. (s.f.). Sobre la naturaleza y efectos de la producción, la distribución y el consumo de la publicidad en la industria cultural. Recuperado de https://dialnet.unirioja.es/descarga/articulo/892686.pdf.

Saussure, F. (1993). Curso de lingüistica general. Madrid, España: Alianza.
Savater, F. (1993, 26 de junio). Leer para despertar. Suplemento Babelia. Diario El País. Recuperado de www.digitalvariants.org, Variants, Fernando Savater

Sloterdijk, P. (2012). Has de cambiar tu vida: sobre antropotécnica. Valencia, España: Pre-Textos.

Sontag, S. (1981). Sobre la fotografía. Barcelona, España: Edhasa.

Zambrano, W. (2009). La lengua espejo de la identidad. Investigación. (18), mayo-agosto, 63-65. Recuperado de www.saber.ula.ve/bitstream/123456789/27675/1/articulo19.pdf.

\section{Datos de filiación}

Rita María Pérez es doctora en "Filosofía en un Mundo Global" por la Universidad del País Vasco (UPV/ EHU), España. Es Licenciada en Letras por la Universidad de Oriente de Santiago de Cuba y ha realizado maestría Educación Superior en la Universidad Autónoma de Santo Domingo y maestría en Filosofía, en la Universidad del País Vasco. Se ha desempañado como profesora de Semiótica de la Publicidad y de Sociología de la Comunicación en el Departamento de Comunicación Social y en la Escuela de Comunicación Publicitaria de las Universidades Pontificia Universidad Católica Madre y Maestra (PUCMM) y de la Universidad Iberoamericana (UNIBE) de Santo Domingo, República Dominicana. Actualmente sus investigaciones se enfocan en temas relacionados con la publicidad, la semiótica y la sociedad. Correo: ritamariaperezperez@yahoo.es 